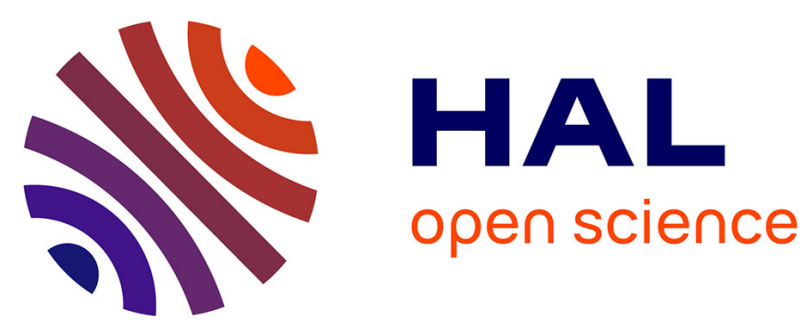

\title{
Introduction. Workers under pressure and social care arrangements: A research framework
}

Trudie Knijn, Claude Martin, Blanche Le Bihan

\section{To cite this version:}

Trudie Knijn, Claude Martin, Blanche Le Bihan. Introduction. Workers under pressure and social care arrangements: A research framework. Work and Care under Pressure. Care Arrangements across Europe, Amsterdam University Press, pp.7-31, 2013, Work and care under pressure. Care arrangements across Europe, 9789089645425. halshs-03089388

\section{HAL Id: halshs-03089388 \\ https://shs.hal.science/halshs-03089388}

Submitted on 4 Jan 2021

HAL is a multi-disciplinary open access archive for the deposit and dissemination of scientific research documents, whether they are published or not. The documents may come from teaching and research institutions in France or abroad, or from public or private research centers.
L'archive ouverte pluridisciplinaire HAL, est destinée au dépôt et à la diffusion de documents scientifiques de niveau recherche, publiés ou non, émanant des établissements d'enseignement et de recherche français ou étrangers, des laboratoires publics ou privés. 
Blanche LE BIHAN, Claude MARTIN \& Trudie KNIJN (eds.), Work and Care under Pressure. Care Arrangements across Europe. Amsterdam and Chicago, Amsterdam and Chicago University Press, 2013, p. 7-31

\section{CHAPTER 1- INTRODUCTION: WORKERS UNDER PRESSURE AND SOCIAL CARE ARRANGEMENTS. A RESEARCH FRAMEWORK}

Trudie Knijn, Claude Martin and Blanche Le Bihan

Reconciling work and family life - or reaching a Work-Family Balance as it is called in recent literature (Guest, 2002; Frone, 2003; Abigail and Milner, 2003; Hantrais and Ackers, 2005; Van der Lippe, Jager and Kops, 2006; Van der Lippe and Peters, 2007; Lewis, 2009a; Hobson, 2011) - is at the core of the European social policy agenda as well as that of many member states. It has also been the subject of (comparative) academic research ever since the 1970s. For a long time the focus of social policies (and of many academic studies) has been on the way gender inequality, expressed in women's family care responsibilities, has restricted women's full participation in the labour market, their career perspectives, (economic) autonomy and independency, social participation and self-development.

Recently, a turning point has been reached, in that the lens is now also directed at the effects of employment on gender-equal family life. This approach can be ascribed to three parallel developments. First, in many countries, the majority of women (with or without dependent family members) are in paid employment, although not always and everywhere full-time (OECD Employment Outlook, 2012). Secondly, the effects of the post-industrial labour market, with its irregular working times, precarious and flexible jobs and increasing productivity, is influencing family life in an unforeseen way (Guest, 2002; Drobnic and Guillén, 2011). Thirdly, evaluations of the diversification of care arrangements (via the state, the market, taxation systems etc.) make clear that the family will remain a last resort of care work. 
The previous perspective that public care should fully substitute - mainly women's - family care has been recognized as unrealistic - and even undesirable. Although men's contribution to family care work has increased, it still lags far behind women's share in family care work, and the focus has been shifted to the dual aims of protecting some time for caring for family members and to reach gender-equal sharing of work and care (Knijn and Kremer, 1997; Lewis, 2009a).

This book reflects these current tendencies, focusing in a detailed and balanced way on how people - mainly women - in six European countries (France, Germany, Italy, the Netherlands, Portugal and Sweden) deal with care responsibilities for their children and older parents in employment conditions that are neither secure, stable not foreseeable. It focuses on the effects of insufficient care provisions on women's relation to the labour market, as well as on the effects on family life and employment in a flexible and insecure labour market, in purely productivity-oriented economy conditions. The intention is to explore and understand, by way of national case-studies, how family members envisage and deal with combining the demands of (nearly or more than) full-time jobs, shift work, and precarious and flexible work schemes with caring for dependent and vulnerable family members ${ }^{1}$. How do post-industrial female and male workers balance work and family life? The main questions investigated in this book are: (i) what defines differences in intergenerational care work for children and frail elderly parents; in what way do conditions for coping with childcare differ from conditions for coping with care for frail elderly family members? (ii) How do women (and men) in various European welfare state cope with balancing work and family life in a context where their working conditions are increasingly complex; and (iii) how do social policies, labour market regulations, workplace conditions and care facilities enable or impede their attempts to achieve a satisfying balance between work and family life?

The relationship between private task divisions and employment, and its trade-offs are still characterized by gender segregation at the labour market; lower wages and limited career perspectives of women on the labour market influence decisions on private task divisions, and vice versa. On the one hand, women's employment rates in all European countries increased

\footnotetext{
${ }^{1}$ This book is the result of a research which received the support of the French national research agency (Agence nationale de la recherche) between 2007 and 2010. This research called WOUPS (Workers under pressure and social care) also received some additional funding in each country to complete the ANR budget. We want to thank the ANR for this support and Alis Sopadzhiyan for her patient work to finalize the manuscript of this book.
} 
during the last decades of the $20^{\text {th }}$ century, with men taking on a larger share of what has been called 'women's work', public services for childcare being expanded in most European welfare states, and provisions for combining work and care being central to the policy agendas of the EU and its member states. On the other hand, new employment patterns - such as long working hours and flexible working hours, temporary and shift work - today influence the way (mainly) women cope with combining care for children and frail elderly parents. Women have to cope with these caring tasks in a context of flexible labour markets and fluid family lives caused by increasing divorce and cohabitation rates, growing numbers of children born out of wedlock and to single parent families, and a family structure that tends to be vertical (intergenerational) rather than horizontal (Saraceno, 2008; Kotowska, 2012; Dykstra, 2012). In consequence, the way women deal with family life and employment is dynamic, related to developments on the labour market and in family life - in the context of family policy, care work and labour market regulations, workplace culture, and interpretations of the meaning of family care. Each of these preconditions has changed the work-life balance in European countries over the previous decades.

Below, we begin by outlining employment patterns and labour market participation in the six countries under study. Then we will summarize the main aspects of the framework having inspired the national case studies to be presented in the following chapters. First we focus on the difference between caring for children and for frail elderly relatives; intergenerational features of the relationship between adult children and their parents as well as between parents and their children, and its cultural interpretation, defining the sense of responsibility and the way in which care work can be managed. The latter is also influenced by social policy. Our second task is to map out care-related options for participating in the post-industrial labour market, and work-related options for family care. Both work-life balance conditions are influenced by national and EU social policies, resulting in fairly diverse coping strategies being applied by women in the six countries under study. Thirdly, we will explore coping strategies that might be used by the respondents represented in the casestudies in this book. Finally, the book's research framework and methodological strategy will be outlined. 


\section{Changing labour markets and the effect this has on work autonomy}

All over Europe, labour markets are in change; the post-war six-day and (since the 1960s) five-day working week, and the regulated daily hours of the Fordist industrial working patterns no longer exist for the majority of the workforce. Only a small minority of the European population now works in agriculture, and industrial work is being rapidly replaced by post-industrial work in banking, insurance companies, police and security services, hospitality and tourism, (health)care, education, the design industry, management, editing and translating, performance, arts, and transport. Jobs in these kind of sectors either demand 24/7 work-shifts, and are neither time-and-place bound nor have to be performed at what were previously considered 'irregular working hours'. During the era of the transformation from industrial to post-industrial labour market, large numbers of women entered deregulated 'post-industrial jobs' offering both opportunities and challenges for family life and care (Lewis and den Dulk, 2008; Lewis, 2009b). And it is precisely because of this deregulation of working times and related protection schemes that it is hard to pin down how the labour market has evolved in terms of flexibility, atypical working timetables in the countries under scope and at EU level; there are variations between countries in terms of labour market characteristics; the number of part-time, flexible (and precarious versus full-time) jobs, and the percentage of self-employed workers.

The OECD Employment Outlook (2012) shows that in the countries we are concerned with, average annual working hours vary between less than 1400 (Germany) and almost 1800 (Italy) - so that German employees work more than 25\% fewer hours per year than their Italian colleagues. It is striking that in Italy only $57 \%$ of the working age population is employed - as against $71 \%$ of the German working population. In consequence, the overall German population appears not to work more than the Italian population; it is just that the country succeeds in better dividing working hours among the workforce. Gender differences in labour participation are also highest in Italy, where it is still the case that less than half of the female population is included in the labour market - $11 \%$ below the (already low) participation rate of men. In all other countries we are concerned with, women's employment is, at most, $5 \%$ below the participation rates of men. There are also interesting differences in terms of parttime employment, which stands at almost $40 \%$ in the Netherlands - a high rate -and is virtually non-existent in Portugal (less than 10\%). Finally, the prevalence of temporary work appears 
to have been fairly stable since 2000 in most of the six countries - with the exception of the Netherlands, where there was an increase in temporary work from $14 \%$ in 2000 to $18.5 \%$ in 2010. By implication, in this country almost a fifth of the working population is employed in a non-permanent job, and in Portugal this figure even reaches $23 \%$.

For an evaluation of the influence of (changing) work conditions on the work-life balance of men and women, Mustomäki, Anttila, Oinas and Nätti (2011) analysed data from the European Working Conditions Survey (1995, 2000-2001, and 2005) and detected an overall gender division in working conditions.

Table 1. Labour market participation and working hours (2010)

\begin{tabular}{|l|c|c|c|c|c|}
\hline & $\begin{array}{c}\text { Employment } \\
\text { rates (\% of } \\
\text { working age } \\
\text { population) }\end{array}$ & $\begin{array}{c}\text { Women } \\
\text { employed } \\
\text { (\% of female } \\
\text { population } \\
\text { 15-64) }\end{array}$ & $\begin{array}{c}\text { \% Part-time } \\
\text { employment }\end{array}$ & $\begin{array}{c}\text { \% Temporary } \\
\text { employment* }\end{array}$ & $\begin{array}{c}\text { Average } \\
\text { annual } \\
\text { working } \\
\text { hours per } \\
\text { worker }\end{array}$ \\
\hline France & 64 & 60 & 13.6 & 15.1 & $1554(2009)$ \\
\hline Germany & 71 & 66 & 21.7 & 14.7 & 1419 \\
\hline Italy & 57 & 46 & 16.3 & 12.8 & 1778 \\
\hline The Netherlands & 75 & 70 & 37.1 & 18.5 & 1377 \\
\hline Portugal & 66 & 61 & 9.3 & 23 & 1714 \\
\hline Sweden & 73 & 70 & 14 & 15.8 & 1624 \\
\hline
\end{tabular}

Source: OECD Employment Outlook

The findings on employee discretionary power (having influence on the daily organisation of work, the order and methods of work), long working hours, often working at unsocial times (defined as working at least four Saturdays/Sundays or at least five nights per month), and job insecurity show interesting results. Mustomäki et al. (2011) conclude that, except in the Scandinavian countries, women have higher discretionary power at work than men. Although lower proportions of working men and women have high discretionary power in less affluent societies, 'the gender gap' is widest in Scandinavia and Eastern Europe, whereas in Anglo-Saxon and Southern Europe men and women report more equal levels of influence on their daily organisation of work (ibid: 31). Especially in Anglo-Saxon countries, but also in Continental and Eastern European countries, men's influence on working hours and the organisation of their work has declined since 2000, and the same goes for women in Southern Europe. As might have been expected, men work long hours per week (48 hours or 
more) in more often than women in all countries included in this survey. The phenomenon of workers working non-standard working hours increased in all countries included in the survey, and this is slightly more common among men than among women. As many as a third of all men, and a quarter of all women, in 2005 worked non-standard working hours, except in Scandinavian countries where less than $15 \%$ of male and female workers work unsocial working hours. (Mustomäki et al., 2011). Finally, there is a great deal of variation in the percentage of workers in temporary jobs in the countries. Mustomäki et al. (2011) show that mainly women in Southern European countries work in temporary jobs - and to a lesser extent, women in Scandinavian countries do so.

The variation in gendered labour market participation rates, average working hours of men and women, job discretionary power at work, and job (in)security in the six countries under study, does not in itself define the work-life balance of family members caring for both children and frail elderly relatives. Local working conditions, family and care policies and culturally defined patterns of intergenerational and gender relations also make up the contexts in which male and female family members construct - and are able to cope with work and care demands for children and frail elderly parents.

\section{Care for children or frail elderly people}

Care of children demands a different kind of caretaking than care of elderly relatives (parents or parents-in-law). These differences have to do with planning, perspective and hierarchical relationships between the generations. With regard to planning, most parents will have made a conscious and even planned choice to have children. They may have given thought to how they would cope with combining work and care (even if outcomes have been inconclusive or unsatisfying); they have considered options for the division of care (leave, formal and/or informal childcare, grandparents) and have probably also calculated the costs of having children, and whether they could afford having them. In spite of (falling) numbers of exceptions (teenage mothers and deserted mothers of new-borns) the vast majority of European children are born because their parents have made a conscious decision and concluded that they were ready to become parents.

In contrast, care for frail elderly parents is neither planned, nor the result of considered action by their adult children. Dependency of older parents just happens. It might happen 
suddenly or slowly, at any older age; it might be caused by mental or physical problems, and it is scarcely predictable. With regard to perspective, the development of children's dependency is more predictable than the insecure development of older people's dependency, and the perspective of how children develop is in general fairly clear; step by step they become more autonomous, independent and self-conscious. Frail elderly people in contrast do not have such a perspective. Instead, their dependency seldom results in recovery - and even if health does stabilize for a while, step by step they will need more care and attention. The moment at which frail elderly parents' transition to a higher degree of dependency can hardly be foreseen - and neither the frail elderly themselves, nor their adult children can really anticipate it. There comes a day when it has to be acknowledged, and adult children have to cope with it.

One major difference between caring for children and for one's frail elderly parents is made up by intergenerational hierarchy. Whereas parents are - by definition and because of their position, age, and by law - responsible authorities in relationship to the immature children they care for, the hierarchical relationship between adult children and the frail elderly parents they care for is much more complicated. Firstly, throughout their lives these adult children have had no say in their parents' lives; at best they may have given some advice once they had become adults. In contrast, they were the ones who had grown up under the responsibility and authority of their parents, becoming more or less equal during their adult lives, and having to cope with a situation of reversed dependency at the end of their parents' lives. Secondly, careful adult children appear to be sensitive to their parents' wishes and feelings, hesitating to quarrel with their parents. Reasons for this might be respect for their parents, feelings of guilt, or just still-present fear of their parents' anger. Thirdly, regardless of how frail and dependent elderly parents are, they have their own opinions on what they need, like and want in a given situation and might not accept their children's advice - even if it is based on what the children refer to as their 'best interests'. Fourthly, adult children usually have no legal authority over their parents, and are therefore unable to act against their will. Finally, the transformation of adult children into 'a semi-parental role' for their own caredependent parents, as Saraceno (2008) calls it, redefines 'boundaries of intimacy that are deeply entrenched in intergenerational roles, and more generally may entail a symbolic 
realignment of memories and emotional biographies (ibid: 8). None of these aspects arise in caretaking for one's own children.

Because the planning, perspective and intergenerational hierarchy are very different in relationships between parents and young children and between adult children and dependent elderly parents, the relational, emotional and social character of each type of caregiving differs. In addition, conditions and resources for both types of caregiving vary, since caring for children and caring for elderly parents are differently facilitated by care-related social policies and work regulations in European welfare states. Hence, the way in which parents and adult children perform their caregiving work also depends on how intergenerational care is facilitated or restricted in their respective countries.

\section{Care packaging: different patchworks for children and frail elderly people}

There are also similarities between caring for elderly parents and caring for children. The degree of dependency - related to the age of the children, or the health of the parents is more of a determining factor than intergenerational hierarchy is deciding the degree of emotional attention, feeding and nurturing, clothing and cleaning needed; all aspects of care work have to be organised, thought about and shared with loyal, trustworthy people - either in the intimacy of private family life or in an institutional context. The concept of carepackaging (Knijn, Jönsson and Klammer, 2005) that goes back to Balbo's (1987) 'quilting or patchwork' care is most relevant here because it refers to the combination of all kinds of resources for care work that in the end has to be integrated, monitored and organised by (female) family members. Since Balbo's publication in 1987, many changes have taken place in the European welfare states' care provision. Cash-for-care payments have been introduced, childcare facilities have been extended in almost all European countries, (unpaid) care leave has been introduced, care work has been valued in pension schemes, and the EU has made (unpaid) parental leave compulsory in its member states (Ungerson and Yeandle, 2007; Lewis, Knijn, Martin and Ostner, 2008; Daly, 2011; Plantenga, Remery and Takacs, 2012).

Nevertheless, huge differences persist between welfare state contributions to care work, as well as between the six countries under study. Sweden, for instance, spent $2.3 \%$ of its GDP in 2008 on elderly care in contrast to the five continental European countries, none of which spends more than $0.7 \%$ (The Netherlands) on elderly care. France contributes $0.4 \%$, 
Portugal $0.3 \%$, Germany $0.2 \%$, and Italy only $0.1 \%$ of their respective GDPs on elderly care (Eurostat, 2010 online data code: tsdde530). Such expenditure data more or less indicates the level of generosity in the kind of care provided. The low spending on elderly care in Italy, Portugal and Germany is reflected in these countries' residential care facilities for persons aged $65+(2 \%, 3.4 \%$ and $3.7 \%$ respectively), while the three other countries offer residential care to $5.9 \%$ (Sweden), 6.7\% (France) and 6.9\% (The Netherlands) of people aged 65+ (OECD Health Data, 2010, for Italy ISTAD 2010b, for Portugal see the chapter 6 in this book).

Expenditure on childcare (services and allowances) also varies widely, with Germany and Sweden each spending 3.1\%, and France, Portugal, the Netherlands and Italy each spending respectively 2.6\%, 1.5\%, 1.3\% and 1.0\% in 2006 (European Parliament, 2006; Da Roit and Sabatinelli, 2007; Martin, 2010), not forgetting the extent to which these estimates can vary, depending of the perimeter of definition we adopt for childcare policies and, in particular, depending whether or not preschool costs are included (Scheiwe and Willekens, 2009). Given the wide range and huge variety of care policies for elderly people and children in the six countries under study, some indications of the main characteristics of these countries' care policies will be summarized in Table 2 by distinguishing a) financially compensated care services (residential/institutional), b) financially compensated professional care work, and c) cash-for-care schemes, and d) (paid) leave.

Table 2. Care services, professional care work, cash-for-care and care leave.

\begin{tabular}{|c|c|c|}
\hline & Elderly care & Childcare \\
\hline France & $\begin{array}{l}\text { a) Residential care for elderly people; } \\
\text { coverage } 6.7 \% \text { of persons }>65 \\
\text { b) Home nursing services (medical) } \\
\text { Allocation personnalisée d'autonomie } \\
\text { c) Benefit for social and personal care } \\
\text { (Allocation personnalisée d'autonomie) } \\
\text { d) Familial solidarity leave to accompany } \\
\text { a dying relative. Three months, } \\
\text { renewable once. Unpaid. } \\
\text { e) In } 2009 \text {, creation of a short paid leave } \\
\text { fixed at } € 47 / \text { day for three weeks to care } \\
\text { for a dying relative ( } 3 \text { weeks only). }\end{array}$ & $\begin{array}{l}\text { a) Crèches' for children under } 3 \text { and day } \\
\text { care centres for older children on } \\
\text { Wednesdays. } \\
\text { b) Cash benefits for qualified } \\
\text { childminders for children under } 3 \text { in the } \\
\text { 1980s } \\
\text { c) PAJE: Prestation d'accueil du jeune } \\
\text { enfant, composed of different elements: } \\
\text { a universal basic allowance up to the } \\
\text { third birthday of the child, a complement } \\
\text { du mode de garde (CMG) for the parents } \\
\text { of a child under six years old who want to } \\
\text { work and the complement de libre choix } \\
\text { d'activité CLCA, a parental leave for }\end{array}$ \\
\hline
\end{tabular}




\begin{tabular}{|c|c|c|}
\hline & & $\begin{array}{l}\text { parents who want to reduce or stop their } \\
\text { employment to care for their children up } \\
\text { to their third birthday (also possible part- } \\
\text { time) }\end{array}$ \\
\hline Germany & $\begin{array}{l}\text { a) Residential care for elderly people; } \\
\text { coverage } 3.7 \% \text { of persons > } 65 \text {. Co- } \\
\text { payment for } 5 \text { days a week, can be > } \\
1,000 \text { euro per month) } \\
\text { b) Benefits for long-term care (insurance } \\
\text { based) } \\
\text { c) Non paid } 6 \text { months care leave for a } \\
\text { dying elderly parent }\end{array}$ & $\begin{array}{l}\text { a) Right to a (part-time) childcare place } \\
\text { d) Legal right to maternity leave ( } 14 \\
\text { weeks) plus } 2 \text { years parental leave, the } \\
\text { latter is paid during } 12 \text { months (or an } \\
\text { equivalent) at } 67 \% \text { of the usual wage } \\
\text { (maximum } 1800 \text { euro). Fathers can take } \\
\text { up two months, but if he does not, the } 2 \\
\text { months are not deducted. Right to } \\
\text { request for part-time work but only for } \\
\text { fulltime workers the right to return is } \\
\text { guaranteed. }\end{array}$ \\
\hline Italy & $\begin{array}{l}\text { a) Residential care for elderly people } \\
\text { (expensive); coverage } 2 \% \text { of persons }> \\
65 \text {. } \\
\text { b) Home care services (reach } 3-4 \% \text { of } 65+ \\
\text { population; health care domiciliary } \\
\text { services (a broader audience restricted } \\
\text { to very specific tasks) } \\
\text { c) cash allowance (indennità di } \\
\text { accompagnamento) for disabled and/or } \\
\text { older people. Beneficiaries must be } 100 \% \\
\text { disabled and be in need of constant care. } \\
\text { d) } 3 \text { days of paid leave/month for care of } \\
\text { a severely disabled person. The health } \\
\text { commission has to certify that the person } \\
\text { is } 100 \% \text { disabled. }\end{array}$ & $\begin{array}{l}\text { a) Childcare facilities (limited for under } \\
3 \mathrm{~s} \text {; universal preschool facilities (age } \\
\text { category 3-6) } \\
\text { d) compulsory maternity leave ( } 5 \text { months } \\
\text { at } 80 \% \text { of last earned wage); parental } \\
\text { leave at replacement rate of } 30 \% \text { of the } \\
\text { wage for a maximum of } 6 \text { months taken } \\
\text { within three years of the child's birth. } \\
\text { Plus a 'take or lose' father's quota. }\end{array}$ \\
\hline $\begin{array}{l}\text { The } \\
\text { Netherlands }\end{array}$ & $\begin{array}{l}\text { a) Residential care for elderly people } \\
\text { coverage } 6.9 \% \text { of persons }>65 \text { (almost all } \\
\text { costs publicly covered) } \\
\text { b) Home care and home nursing services } \\
\text { via compulsory insurance paid by } \\
\text { employers' and employees' premiums. } \\
\text { c) Cash-for-care (personal budget) to } \\
\text { care for disabled children and dependent } \\
\text { family members, via compulsory } \\
\text { insurance paid by employers' and } \\
\text { employees' premiums. } \\
\text { d) Emergency leave for unexpected } \\
\text { personal family problems ( } 1 \text { day fully } \\
\text { paid); } 10 \text { days' leave/year to take care of } \\
\text { a relative where the person is the main } \\
\text { carer. Paid } 70 \% \text { of salary; long-term care }\end{array}$ & $\begin{array}{l}\text { a) Childcare facilities (commercially } \\
\text { provided) available for children under } \\
\text { school age (age 4) (coverage rate } 33 \% \text { ), } \\
\text { parental costs reimbursed by income } \\
\text { related tax reductions; Full-time (10- } \\
\text { hour) school day in all primary schools, } \\
\text { with obligatory pre- and after-school } \\
\text { services. } \\
\text { d) short ( } 16 \text { weeks) full paid maternity } \\
\text { leave; parental leave (low paid: } 50 \% \text { of } \\
\text { the minimum wage per hour of leave, } \\
\text { with a maximum ceiling of } 690 \text { Euro per } \\
\text { month, length: } 50 \% \text { of the previous } \\
\text { working week for a period of } 52 \text { weeks; } \\
\text { emergency leave ( } 1 \text { day fully paid); long- } \\
\text { term care leave (for a maximum period } \\
\text { of six times the weekly working hours for }\end{array}$ \\
\hline
\end{tabular}




\begin{tabular}{|c|c|c|}
\hline & $\begin{array}{l}\text { leave to take care of a very sick close } \\
\text { relative (child, parent) (for a maximum } \\
\text { period of six times the weekly working } \\
\text { hours during } 12 \text { weeks, the employee is } \\
\text { allowed to work no more than half of the } \\
\text { number of hours he/she would normally } \\
\text { work). }\end{array}$ & $\begin{array}{l}\text { a period of } 12 \text { weeks, the employee is } \\
\text { allowed to work no more than half of the } \\
\text { number of hours he/she would normally } \\
\text { work). }\end{array}$ \\
\hline Portugal & $\begin{array}{l}\text { a) Residential care for elderly people } \\
\text { coverage } 3.4 \% \text { of persons }>65 \\
\text { b) Home care services (universal, publicly } \\
\text { subsidized offered by non-profit care } \\
\text { providers. Payments according to } \\
\text { income: only very low income families } \\
\text { (below the minimum national wage: } 485 \\
\text { Euros in 2011) are entitled to free } \\
\text { services } \\
\text { c) Cash-for-care schemes; a low flat-rate } \\
\text { benefit per child or dependent elderly } \\
\text { person needing care provided by a third } \\
\text { person. } \\
\text { d) } 15 \text { days to care for a sick adult relative }\end{array}$ & $\begin{array}{l}\text { a) Childcare services (Hybrid: private } \\
\text { non-profit, public and private profit- } \\
\text { making services) with } 47 \% \text { of } 0-2 \text { year } \\
\text { olds enrolled; full-time (8-hour) school } \\
\text { day in all primary schools, with obligatory } \\
\text { pre- and after-school services. } \\
\text { d) Parental leave based on individual } \\
\text { entitlement; paid paternity leave (four } \\
\text { weeks with a bonus month for fathers) } \\
\text { parents can take up } 6 \text { months of well- } \\
\text { paid leave (at } 100 \% \text { of previous } \\
\text { earnings); the right to miss work for } 30 \\
\text { days to care for a sick child; "parental" } \\
\text { entitlement to the 2-hour work } \\
\text { reduction during the first year of the } \\
\text { child's life. }\end{array}$ \\
\hline Sweden & $\begin{array}{l}\text { a) Residential care for elderly people } \\
\text { coverage } 5.9 \% \text { of persons }>65 \\
\text { b) Publicly financed (an income related } \\
\text { fee determined by the municipalities up } \\
\text { to a maximum limit set by the } \\
\text { government); tax deductions to secure } \\
\text { care provision for individuals through the } \\
\text { market. } \\
\text { d) leave: } 2 \text { months to care for a dying } \\
\text { relative, } 80 \% \text { financial compensation }\end{array}$ & $\begin{array}{l}\text { a) Universal childcare; municipalities are } \\
\text { obliged to provide childcare services } \\
\text { (pre-schools) Coverage rates in } 2009 ; \\
79 \% \text { of all children aged one to three and } \\
98 \% \text { of all children aged four to five were } \\
\text { enrolled in formal child care. } \\
\text { b) Childminders' subsidies granted by } \\
\text { municipalities (to purchase care from } \\
\text { private providers, or to provide care } \\
\text { oneself when the child is not enrolled in } \\
\text { public child care). The allowance is } \\
\text { approximately } 300 \text { euros per month and } \\
\text { child before taxes. } \\
\text { c) Legal right to } 14 \text { weeks maternity leave } \\
\text { and } 2 \text { weeks paternity leave. Parental } \\
\text { leave is guaranteed for every qualifying } \\
\text { employee during } 18 \text { months, of which } \\
480 \text { days are paid. Parents are allowed to } \\
\text { reduce their working hours with } 25 \% \text { till } \\
\text { the child is eight. Qualifying parents } \\
\text { receive } 80 \% \text { of their usual wage with an } \\
\text { extra bonus for fathers who take leave. } \\
\text { The right to return to work is guaranteed } \\
\text { unless parents take up more than } 18 \\
\text { months of leave. }\end{array}$ \\
\hline
\end{tabular}


Source: data collected by the WOUPS research team.

In spite of all these facilities, and supported by cash-for-care schemes and legal rights to (paid) leaves, family care still makes up the largest part of all care work that has to be done, even in those countries having well-developed public care facilities. As can be concluded from this overview, European countries differ considerably in the way they provide, facilitate and subsidize provisions for the two categories of dependent family members. By consequence, the way intergenerational care is packaged differs both by country and within countries, between the two categories of caregivers (parents and informal (paid) adult children) as well as between localities (since local inequalities also exist in terms of level and availability of services). In addition, the care package depends (aside from culturally defined care traditions and the quality assessment of care provisions) on family income and working times.

Here we will mainly focus on the relationship between working times and care packages. Only a very small minority of frail elderly parents of adult children are cared for in residual elderly homes - the vast majority being cared for by a combination of professional care services, paid or unpaid informal caregivers, and (several) adult children who must combine this care work with their jobs.

A central question in this book is whether, and how, current macro-level care policies and financial compensations for family care result in what kind of 'care packages' and in what way these allow (female) family caregivers to keep their (almost) full-time jobs and reach a manageable and satisfying work-life balance. It might be clear, on the one hand, that 24/7 residential care for children and elderly parents will offer workers the maximum solution for participation on the labour market. Although such care provision does exist - for instance, at a Toyota childcare centre in the USA - it barely contributes to a satisfactory work-life balance. Also full outsourcing of care to private (migrant) childminders or careworkers for elderly people only benefits participation on the labour market, without contributing to satisfying family relationships (Da Roit, 2010; Hochschild, 2012). On the other hand, research shows that intergenerational relationships prove more satisfying if only part of the full burden of care for frail elderly parents, falls on the shoulders of adult children. Scandinavian elderly people are much more content with the relationship with their children than Italian elderly people are. Reverse dependency is not exactly what older parents desire in relationship to their adult children (Knijn and Komter, 2004; Ostner, 2004) and in some countries, such as the 
Netherlands or France, elderly people are very outspoken about their refusal to become dependent on their children - which sometimes leads them to take out private insurance policies against dependency, as in the French case (Da Roit, 2010; Le Bihan and Martin, 2010).

So neither extreme - full public or full private care - appears to be in line with what dependent elderly people and their adult children long for, and the same goes for parents of young children. Considering the complementarity of these private and public resources, the question is, therefore: what kind of care package is most satisfying, given the working conditions of the family care givers? Such a perspective raises the question of the caregiver's point of view on their care arrangements - in terms of satisfaction, preference, pressure or burden, etc. Interestingly, as case-studies will show, there is no straightforward relationship between the care package offered at the macro-level of the welfare state and the individual care package of women who care for children or frail elderly parents. Some care policies to date offer choices for care work performed by either family members or professional careworkers. In many countries cash-for-care payments can be attributed in both ways, leaving the decision to family members as to which kind of care they prefer. However, the options are never income or gender-neutral, and may have consequences for employment perspectives. The same goes for paid parental leave; while it compensates, on the one hand, for the income loss of the caring parent/mother, on the other it downgrades her "employability". For that reason, many family care workers strive for an optimal care package combining some paid or unpaid family care with some public and/or paid-for professional care services that are assumed to be qualitatively guaranteed, and fit to the family workers' employment demands. So the question is: what precisely is the optimum combination of resources in terms of care arrangements?

The following chapters focus on the considerations these caregivers have and the decisions they make, given their constraints and employment patterns, about the kind of care package they use to balance their work and family life. Will they outsource care work as much as possible because they can afford it, or because they have to? Will they package up as many care resources they can get to optimize their income position, or will they prioritize all kind of family-related care resources because of moral obligations, gendered patterns of care and implicit or explicit expectations of significant others? Do they experience free choice in favour 
of the care package they prefer, or are they trapped between working demands and lack of suitable care facilities? Do these combinations vary substantially depending on country?

A second feature of this care package is that care policies appear to be the most dynamic of all current social policies. Demographic changes, the increasing dependency ratio, pension costs, and costs of elderly care result in an intensive political debate on family and care policy. Hence, continuous and successive reforms challenge the boundaries of public versus private responsibilities, enforcing marketization and commodification of care services, commodifying or facilitating the outsourcing of family care. Reforms are inspired by a wide amalgam of political ideologies - neo-liberal, communitarian or social-democratic - and while certain reforms contribute to de-familializing care, others, conversely, re-familialize it. No matter what the political ideologies behind these reforms are, such rapid transformations certainly contribute to insecurity about future arrangements, raising questions about the reliability and accessibility of public provisions. Such uncertainties are expressed by Swedish adult caregivers, who are experiencing increasing privatization of elderly care, by French caregivers, who are preoccupied by the trend towards resorting to private insurance policies to complement the long-term care system as regularly announced by politicians and decisionmakers, by Italian daughters, who are uncertain about the cash-for-care schemes they use to pay the migrant women caring for their frail and dependent elderly parents, and by Dutch parents of young children who experience continuous reforms in parental leave schemes and private contributions to childcare costs.

\section{Work-related options for care work}

Though working people with care responsibilities do consider their preferred care package in relation to the care needs of their children or frail elderly dependents, they also have to consider it in the context of their working obligations, their options in providing an income for the family, their work ambitions and work-related social policy and regulations. Working habits in their particular jobs and sector are also influential on the options available to them in reaching a satisfying work-life balance. Fagan and Walthery (2011) distinguish four job characteristics which are assumed to cause tensions for individual workers and have a negative impact on work-life balance. Based on a review study by Lyonette and Clark (2009), an initial source of such tensions is long working hours and non-standard working times - and 
even more so where workers do not have control over their work schedules. Fagan and Walthery's assumption is that the negative effects occur because this impairs the worker's "ability to 'switch off' and be emotionally available for involvement in personal life" (ibid: 73). In addition it might be assumed that long working hours and non-standard working times not controlled by employees are directly responsible for difficulties in planning, because of the unpredictability of availability for dependents in need of care.

The second source of tensions distinguished by Fagan and Walthery (2011) concerns job demands. Pace, emotional and cognitive demands can have either positive or negative effects on individually-experienced tensions and ability to reach a satisfactory work-life balance. A positive effect might be that the work compensates for the lack of cognitive demands that goes along with family care work. Performing emotional professional work might contribute to skills that can be used in private family care, and pace demands at work might be experienced as a welcome speeding up in contrast to the - sometimes slow and boring - time spent accompanying very young children or mentally-disabled elderly parents. Negative effects might be caused by an overload of these job demands, which cannot be compensated for because of a lack of private free time due to care responsibilities.

A third source of tensions relates to job control, especially task autonomy, task flow, and time and pace related control. Each of these aspects of task control is assumed to influence work-related strains and therefore the experienced work-life balance. A central conclusion from the study is that: "reports of work-life balance are reduced by long, unsocial working hours and job demands (emotional labour and time pressures) while working time autonomy and job control (over the pace of work, and ask discretion) enhance the work-life balance of European employees." (Fagan and Walthery, 2011: 90).

Social policy and collective work agreements contributing to a more satisfactory worklife balance have been on the policy agenda for some decades - and if applied well, these might offer family caregivers the resources they need to cope with long and/or unsocial working hours. Job demands and job control aspects in turn are not covered by collective agreements or social policy; they are at the discretion of companies, organisations and their managers. Work-related policies governed by social policy and collective work agreements include the right to part-time work, parental leave, and social rights related to part-time, flexible and precarious jobs. In spite of European guidelines for parental leave (Council Directive, 1996), 
and recommendations and agendas for flexicurity (EC, 2007), the way these are implemented (if at all) in member states, varies a great deal. Most striking is the difference between France, the Netherlands and Sweden - countries in which the right to reduce working hours is regulated - and Italy, where such rights are absent. The social protection of employees working in precarious jobs also differs across Europe, varying from fairly robust protection in the Netherlands and Sweden to much weaker configurations in Portugal and Italy, with France and Germany positioned in the middle ground.

However, whether or not collective agreements, rules and social policies are available, in the end workplace culture and management discretion are decisive in workers' ability to make use of it. As den Dulk and colleagues have shown: 'it is at the workplace and workorganisational level that formal work-life policies are converted into entitlements and claims, where requests are granted or denied' (den Dulk, Peper, Sadar, Lewis, Smithson and van Doorne Huiskes, 2011: 301). Arguments for granting (or not) a request for a work-life arrangement have to do with a fear of disrupting the department's work, a fear of losing a valued and hard-to-replace worker, or ethical considerations. This last implies that supporting working parents is a morally correct thing to do (ibid). In addition, findings in the banking sector in three European countries (the Netherlands, Slovenia and the UK) indicate that in all cases, deeply gendered assumptions are still common vivid among banking sector managers, who frame work-life arrangements as being mainly a women's issue (den Dulk et al., 2011).

\subsection{Coping with care work and work under pressure}

Reaching a satisfying combination of caring for those one cares about and fulfilling the demands of one's job is anything but an easy task. The concept of work-life balance is becoming popular as a positive way of expressing the aim of reconciling working life with family life in a gender-equal way. Yet, at the same time, it implicitly gives voice to the tensions between working men and women because the reconciliation is hard to reach on a gender equal basis.

Theoretically, several approaches of the tensions between work and family life as well as between men and women can be distinguished. A long-used framework for explaining tension between these two domains is the 'role strain' theory (Goode, 1960, French and Caplan, 1972; Drobnic and Guillén, 2011). This approach focuses primarily on the structural characteristics of both domains, assuming that work and family life are opposite life domains, 
each demanding different roles that are difficult to combine. The 'role demands' of these opposite domains are characterized by different obligations, qualities and skills. In addition, practical aspects - such as contradictory demands related to the place one needs to be at a certain moment, timing and attention - can hinder the combination of both roles. In line with this approach is the 'coping theory' (Lazarus and Folkman, 1984) which indicates that people, as active agents, are able to cope with stressful life events or conflicting role demands in several ways. Weiten and Lloyd (2008) distinguish three strategies applied in managing circumstances or events experienced as burdensome: (i) 'appraisal focused coping strategies' that are adaptive and cognitive. People deny the burden and/or reformulate and redefine the situation by altering their personal values and goals; (ii) 'problem focused coping strategies' adapt the conditions and circumstances that have brought about the problem. They try to alter conditions by searching for information, and looking for alternative solutions; (iii) 'emotion oriented coping strategies' aim to manage feelings and mindset in order to deal with negative feelings. People try to adjust mentally to what are experienced as given and unchangeable life conditions.

Another theory in line with the two previous ones has been elaborated around the notion of "quality of life and work" (Bäck-Wiklund, Van der Lippe, den Bulk, Doorne-Huiskes, 2011; Drobnic and Guillén, 2011). The core of the model is a 'demands versus resources' approach: "Both the workplace and the family or household situation generate demands and resources. Our basic assumption is that paid work contributes to people's quality of life as long as their resources are adequate to meet the demands and needs they face... When resources lag behind the demands workers face in various life domains, tensions and feelings of stress may arise that in turn impact on their well-being" (Bäck-Wiklund et al., 2011: 18). This perspective is still very much centred on resources to cope with the needs, putting aside the norms and expectations of the individuals. Indeed, important individual variations exist beside common apparent needs and constraint, depending of personal expectations and norms concerning the caring role.

When applied to working adult children caring for elderly parents, and to working parents of young children, this may bring forward quite different ways of dealing with what might be experienced as conflicting role demands, hard-to-combine work and care needs, overload, pressure or simply incompatible work and care places and times. Do adult children 
adjust their definition of the situation once their parents become dependent on their daily care, rephrasing their identity in such a way that they experience themselves more as responsible care givers than as full-time workers? Or do they instead invest as much as possible in maintaining their identity as workers and find substitute caregivers for their parents - either supported or not by such public resources as cash-for-care payments? Or do they consider that their caring role needs to be assumed in a satisfying way to maintain a strong work involvement and integration, with one dimension (the worker role) complementing the other (the caregiver role)?

Our case studies show that these different options and scenarios are put into practice, and that the choice of coping strategy depends less on social policy instruments stricto sensu than on employers' generosity in offering flexible working conditions (as in the Netherlands and (taly), which in its turn influences the way adult children are able to juggle with competing demands and combine resources. Alternatively, parents of young children may be more inclined to adjust their feelings and mindsets than adult children of dependent frail elderly parents do, because (most of the time) they have made a conscious decision to have a caredependent child. Nevertheless, young parents are not always able to foresee the time it will take to care for young children; their working conditions and working times may change, they may feel disappointed in the quality of the care services on offer or - a worst case scenario they were counting on the support of their own parents who suddenly become in need of care themselves. If those things happen - and the following chapters show that they do - they also will have to cope with the resulting strain. But the care arrangements revealed by our collective research also depend fundamentally on the social representations and social norms concerning care tasks, which can vary dramatically depending on social class, generation and culture, as well as over time.

Another and more recent approach to dealing with tensions between work and family life is the 'capabilities approach', as applied by Hobson (2011) and colleagues. Here the assumption is not that work and family life are based upon two different roles that individuals have to cope with. Instead the assumption is that individuals - men and women alike - strive for fulfilment of their capabilities in both domains of life by active agency. Not roles but institutional frameworks - organisational constraints, social policy frameworks, and gendered family structures - limit agents in their ability to achieve a satisfying combination of work and 
family life. By applying this approach to several case-studies, Hobson, Fahlen and Takacs (2011) found that stronger collective agreements not only result in better job protection but also improve workers' agency in requesting adjustments to working hours, refusing to work additional hours or demanding more flexible hours. 'Perceptions of insecurity in jobs and precarious economies are indicators of agency inequalities for Work-Life-Balance.' (ibid: 191). Under those conditions, low-educated women in particular experience a gap between formal rights and the ability to make exercise them, while men struggle to exercise their rights because the workplace culture assumes that, rather than being carers themselves, they are related to women who perform the family care work. An interesting finding of this study is that strong implementation of care-related social policy results in its becoming embedded in organisations, companies and firms, influencing everyday practice at the workplace. The Swedish respondents in this study assert that they are rarely asked to work unsocial hours or do overtime because their manager, employers and colleagues are aware that they have young children (Hobson et al., 2011). An example of this mechanism can also be found in this book. In the Dutch case-study it will be revealed that Dutch employers leave employees who are carers a great deal of room for manoeuvre.

\section{This book}

The chapters in this book do not systematically apply a theoretical approach on how working adult children and working parents deal with caring for their very old and very young family members. Instead of starting from a unique theoretical approach, whether it be a role strain theory, coping strategies, quality of life or a capabilities approach, they dive into real live and let parents as well as adult children talk about the way they solve the tension between the way they interpret the needs of their children, the demands of their parents, the claims of their employer, the insecurity of their jobs and the quality of the care workers who take care for their relatives at the times they are not able to do it themselves.

Therefore we apply a qualitative approach to the practices of care that are embedded in national public care interventions and facilities. In doing so, we have been able to discover the impacts of a rapidly-changing labour market (featuring increased job insecurity and precariousness), on the one hand, and a rapidly- changing social care policy background, on the other hand. This point of view has many advantages: first, it helps to realise the incredible 
diversity of factors and resources that are combined in the policy framing of specific care arrangements framing, also revealing their concrete combination and variation over time in a given case; second, it helps us to realise that there is much more convergence between workers reconciliation strategies than usually is considered in social sciences - at least when priority is given to macro analysis of the policies at the expense of the user or citizen point of view; and third, this perspective raises new questions concerning such invisible factors as those explaining that the feeling of pressure doesn't necessarily co-vary with the level of strain, rather depending more fundamentally on the level of social expectations concerning the carer's role.

Studying behaviours of caregivers in six national contexts therefore highlights the influence of different 'care cultures', social milieu and gender; the relative importance of the feeling of responsibility and/or obligation with regard to children and elderly relatives; the terms of arbitration mobilized by actors to meet the contradictions and constraints imposed by the difficult coordination of working conditions and regulations. The issue is therefore less to show that a certain national configuration provides better conciliation, than to identify what is common and dissimilar to caregivers in their daily life experience. In doing so,

\subsection{The sample}

Our respondents are selected on basis of several criteria: All work long or unsocial hours, and belong to a bi-parental or lone parent household; they have caring responsibilities for young children, and/or dependent relatives. In our sample, we distinguished between two types of workers and caring needs: parents with young children, either dual parent or loneparent households with long or non-standard hours of work; and senior workers (45-65 years old) with at least one dependent relative. These two categories refer to different generations, different periods of the life course, and different care responsibilities.

In addition we took into account:

- Working-time characteristics. Though all adult-carers of elderly parents have long working days, bi-active parents of young children also have non-standard hours of work, which cover very different situations (very long working days, work on Saturday and Sunday, work during the night, shift work, etc.). In terms of pressure, these nonstandard working hours introduce two main variables: the level of predictability of 
working hours and how negotiable it is - in terms of either the company or other team members.

- Sector of activity, whether private or public; in each country we have chosen certain sectors of employment in which non-standard working patterns are particularly welldeveloped (retailing, hospitals, commercial activities, IT).

- Level of worker qualification; salary levels; type of employment contract or worker's status;

- Informal network resources: proximity of grand-parents or other family members for the younger generation with young children; proximity of siblings for the older one with elderly parents.

Table 3: Composition of the WOUPS sample

\begin{tabular}{|l|c|c|c|}
\hline & $\begin{array}{c}\text { Carers working with } \\
\text { non-standard hours } \\
\text { and childcare } \\
\text { responsibilities }\end{array}$ & $\begin{array}{c}\text { Carers working with } \\
\text { elderly care } \\
\text { responsibilities }\end{array}$ & Total \\
\hline The Netherlands & 15 & 20 & 35 \\
\hline Portugal & 21 & 23 & 44 \\
\hline France & 21 & 17 & 38 \\
\hline Germany & 15 & 26 & 41 \\
\hline Italy & 26 & 26 & 52 \\
\hline Sweden & 17 & 17 & 34 \\
\hline Total & 115 & 129 & 244 \\
\hline
\end{tabular}

The following chapters present these national cases. Each national team, informed by our common experience and international meetings throughout the course of our three-year project, presents its respective empirical material, explaining the main lessons and issues. Each team chooses the perspective from which to answer our collective questions but also pays attention to the development of an innovative point of view. In Chapter 2, on the Netherlands, Trudie Knijn and Barbara Da Roit demonstrate that the reconciliation issue is still very central, even in this "part-time" work model, where it is generally considered that the mainly female part-time jobs resolve the issue of conciliation. Through this national case study, we have gained understanding of the extent to which large or macro-comparisons overlook the mechanisms that mediate between policies, individual attitudes and practices. Dutch material reveals an ambivalent pattern of attachment to employment and detachment 
from one's job: as formulated by the authors, "caregivers are attached to being in employment, but rather 'detached' from their particular job". This national case also demonstrates the importance of the gendered work and care culture shared by all agents (employers and employees), which influences behaviour in combining work and care.

Chapter 3 looks at the Swedish configuration. Sofia Björk, Ulla Björnberg and Hans Ekbrand get over the common cliché about Swedish equal-gender rhetoric, insisting on the significant gender gap which still exists with regard to the carer role. Many more mothers than fathers allow their childcare responsibilities to take precedence over work, and for the same reason, daughters are much more involved in elderly care than sons are. In fact, caught in their feelings of guilt for not spending enough time with their children, working mothers report having more difficulties than fathers in considering themselves "good parents". Another cliché which is questioned in this chapter is the generally high level offer of services which facilitates reconciliation both for parents of young children and adults with elderly relatives. Recent developments and reforms show that even Sweden is facing a significant decrease in public care services. And this downsizing of public care in a culture of gender equality and public services has negative consequences for gender equality, in that any transfer of responsibilities from public care providers to families tends to mean transferring them further onto the shoulders of women.

Chapter 4 focuses on the ways in which socio-economic conditions affect the caregiving strategies and arrangements of individuals and households in the German policy context. Wolfgang Keck, Christina Klenner, Sabine Neukirch and Chiara Saraceno underline a process which increases inequalities, since socio-economic inequalities in financial resources and job and career prospects also determine the opportunity costs incurred when reducing working time or giving up one's job. On the one hand, the higher the income (and level of investment made in achieving and maintaining the current position), the less likely it is that caregivers will resign from their job or reduce their working hours, leading to inequalities not just between women and men but also between women. On the other hand, employees in low-paid jobs have lower opportunity costs when reducing their time in paid work, which explains why they more easily accept a reduction in working hours - or give up their job altogether, which seems to be one objective of the social and employment policies followed in this country. In Germany, where the division of labour among parents is often traditional, 
combining paid employment and caregiving is a difficult exercise, and one which receives little support from policy and even less from employers. As the authors state: "only those who can count on systematic family support or who have the financial means to pay for additional care, or both, may overcome the constraints from limited public support".

In chapter 5, Blanche Le Bihan, Claude Martin and Arnaud Campéon propose a focus on French caregivers' experiences of pressure. The authors make a distinction between the level of constraints and the feeling of pressure, observing that pressure related to the difficulties of juggling work and care is not just due to the (objective) accumulation of strain. Pressure is indeed related to working conditions (working hours, employment stability), family structure (two-parent or single-parent household; only child or not) and caring responsibilities. Yet other elements also play a crucial role - such as the importance of the quality of the care arrangement and the feeling of satisfaction or dissatisfaction related to it, or the nature of the relationship between the siblings and between the carer and the caredfor. Therefore, constraints can only explain part of the difficulty working carers are confronted with. One must also consider the way people feel, or their self-representation of the various constraints. These subjective variables, which can only be approached through in-depth qualitative inquiries (and in particular the representations that parents and adult children have of their own roles and satisfaction or dissatisfaction at work) are important elements to consider.

In Chapter 6, Karin Wall, Sanda Samitca and Sonia Correia present the Portuguese case study. Once again, one objective of this chapter is to go beyond the common cliché about Portugal as a family-based society. The authors insist on the important changes that have taken place over the past few decades in the articulation between work and family life, explaining how these changes and reforms interact with families' care norms and practices, with particular regard to the longstanding influence of a familialistic culture which stresses strong intergenerational obligations. The result of these rapid transformations (in family structures and behaviours, in terms of social care policies and on the labour market) lead to a mixed-welfare or mixed-care system that imposes complex combinations of resources, public and private, in order to face the dual earner predominant model with full-time breadwinners and caregivers. The mixed social care model is particularly evident in elderly care, which includes both home-based and residential care, both family and paid informal carers, both 
publicly subsidised and private service provision. Work/family policies for child care and for elderly people have, however, followed slightly different paths. Child care policies have increased both leave and services to support dual earner families (defamilialization), whereas policy concerning care for elderly people, developed later, is less based on defamilialization.

In chapter 7, Manuela Naldini, Elisabetta Donati and Barbara da Roit present the Italian case - a highly familialized care system with a low public service offer, but also, as they argue, a work/family balance shaped by generational dependencies and interdependencies. The authors insist on what they call the "blurring boundaries" (not only between different types of care (formal and informal, paid and unpaid), but also between households) and the resulting clash of loyalties in the distribution of time between oneself, children, couple, family and elderly parent(s). In the Italian case, carers have to significantly mobilise resources belonging to other generations; a configuration which doesn't seem to raise any problems concerning a potential gap between different educative models. "Italian caregivers living in dual-earner couples adopt solutions which result from a complex bricolage of strategies moving across different spaces, across individual and family life-course phases, through commitment to working and caring related to traditional or innovative roles". This care arrangement configuration, however, confronts caregivers with a potential conflict, given that their own parents may themselves become in need of support, rather than being secondary caregivers. In Italy, as in the France and to a certain extent in the Netherlands, female carers consider the maintenance of their own jobs to be non-negotiable - a real necessity not only for economic reasons, but also in order to keep their own identity and network.

In this last chapter, Manuela Naldini, Karin Wall and Blanche Le Bihan investigate one of the main lessons of our collective work: the development, across all the countries studied, of a "mix of care". As we argue in this introduction, our perspective has been deliberately centred on the level of care arrangements. And, contrary to the usual comparative lessons (which, in accordance with the available typologies, insist on the gaps or differences between countries) on the respective performance of one set of policies compared to others, we reveal some common trends in quite different welfare regimes, but also intra-national common differences depending on social class, gender, generation and sector of intervention (childcare and elderly care). In these concluding remarks, the authors come back to, and discuss, the main concepts and dichotomies used in the social care debate (e.g. 
familialization/defamilialization, public/private, generous/sparse leave-to-care schemes, formal/informal and semi-formal care, etc.), and depict variations around a common trend: the move towards a mixed care system mobilising different set of resources. The two main questions posed by Manuela Naldini, Karin Wall and Blanche Le Bihan are: How do carers working long or non-standard hours themselves perceive and practice this emerging mixed care? Does the mix of care take on similar or different forms in the cases of care of young children and of dependent elderly persons?

At the end of this project, we hope to offer an original contribution to the social care debate, in a context in which social transformations are happening particularly fast. What we observed in 2007 and 2008, when we were collecting our data, changed rapidly afterwards due to the financial crisis and the incredible impact it has had since then. It is more than probable that the tensions between work and family life we have exposed in the WOUPS project will last, and therefore urge for continuous awareness of changes at work.

\section{References}

Abigail, G. and Milner, S. (2009), 'Work-Life Balance: A Matter of Choice?', Gender, Work and Organization, $16(1)$ : 1-13.

Bäck-Wiklund, M., Van der Lippe T., Den Bulk L., Doorne-Huiskes A. Van (eds), (2011), Quality of Life and Work in Europe. Theory, Practice and policy. London: Palgrave Macmillan.

Balbo, L. (1987), 'Family, Women and the State: Notes towards a Typology of Family Roles and Public Intervention', in C. S. Maier (ed.), Changing Boundaries of the Political: Essays on the Evolving Balance Between the State and Society, Public and Private in Europe. Cambridge: Cambridge University Press.

Blome, A., Keck, W. and Alber, J., (2009), Family and the Welfare State in Europe. Cheltenham: Edward Elgar Publisher.

Council Directive 96/34/EC of 3 June 1996 on the framework agreement on parental leave concluded by UNICE, CEEP and the ETUC.

Daly, M., (2005), 'Changing family life in Europe: Significance for state and society', European Societies, 7 (3): 379-398.

Daly, M., (2011), 'What Adult Worker Model? A Critical Look at Recent Social Policy Reform in Europe from a Gender and Family Perspective', Social Politics. International Studies in Gender, State and Society, 18 (1): 1-23.

Da Roit, B. (2010), Strategies of Care. Changing Elderly Care in Italy and the Netherlands. Amsterdam: Amsterdam University Press. 
Da Roit, B., Sabatinelli S. (2007) The Cost of Childcare in EU Countries. Report presented to the European Parliament's Employment and Social Affairs Committee (IP/A/EMPL/FWC/SC/2006-05/SC1), Brussels: European Parliament

den Dulk, L., Peper, B., Sadar, N.C., Lewis, S., Smithson, J. and Van Doorne-Huiskes, A., (2011), 'Work, family, and managerial attitudes and practices in the European workplace: comparing Dutch, British and Slovenian financial sector managers' Social Politics, 18 (2): 300-329.

Drobnic, S. and Guillén, A.M. (eds), (2011), Work-Life Balance in Europe. The Role of Job Quality. Hampshire: Palgrave Macmillan.

Dykstra, P.A. (Ed.). (2012). Intergenerational family ties in Europe: Multiple linkages between individuals, families and social contexts. Demographic Research: Special Collection 11.

European Commission, (2007), Towards Common Principles of Flexicurity: More and Better Jobs through Flexibility and Security. Communication to the European parliament, the Council, the European Economic and Social Committee and the Committee of the Regions. Brussels: COM 2007/861-862.

Fagan, C. and Walthery, P., (2011), 'Individual working-time adjustments between full-time and part-time working in European firms' Social Politics 18 (2): 269-299.

Frone, M. R., (2003), 'Work -Family Balance', in J.C. Quick and L.E. Tetrick (eds), Handbook of Occupational Health Psychology, Washington DC: American Psychological Association: 143-162.

Guest, D.E., (2002), 'Perspectives on the Study of Work-Life Balance', Social Science Information, 41 (2): 255-279.

Hantrais, L and Ackers, P (2005), Women's Choices in Europe: Striking the Work-Life Balance, European Journal of Industrial Relations, 11(2), pp.197-212

Hilbrecht M., Shaw, S. M., Johnson, L. C. and Andrey, J., (2008), 'I'm Home for the Kids': Contradictory Implications for Work-Life Balance of Teleworking Mothers. Gender, Work and Organization, 15 (5): 454-476.

Hobson, B., (2011) 'The Agency gap in work-life balance: applying Sen's capabilities framework within European contexts', Social Politics, 18 (2): 147-167.

Hobson, B., Fahlen, S. and Takacs, J., (2011), 'Agency and capabilities to achieve a work-life balance. A comparison of Sweden and Hungary', Social Politics, 18 (2): 168-198.

Hochschild A. R. (2012), The Outsourced Self: Intimate Life in Market Times. New York: Metropolitan Press.

Kay, T., (2003), 'The Work-Life balance in social practice', Social Policy and Society , 2: 231239.

Knijn, T. and Kremer, M., (1997), 'Gender and the Caring Dimension of Welfare State: Toward Inclusive Citizenship', Social Politics, 4 (3): 328-361.

Knijn, T. and Smit, A., (2009), 'Investing, facilitating or individualizing the reconciliation of work and family life: three paradigms and ambivalent policies', Social Politics, 16 (4): 484518. 
Knijn, T. and Komter, A. (eds), (2004), Solidarity Between the Sexes and the Generations. Transformations in Europe, Cheltenham: Edward Elgar.

Knijn, T. and Smith, M., (2012), 'European Union and member states' Youth policies agenda' in T. Knijn (ed.) Work, Family Policy and the Transition to Adulthood in Europe. Palgrave, Macmillan. Pp. 39-76.

Knijn, T., Jönsson, I. and Klammer, U., (2005), 'Care packages: the Organisation of Work and Care by Working Mothers', in U. Gerhard, T. Knijn, and A. Weckwert (eds.), Working Mothers in Europe. A Comparison of Policies and Practices, Cheltenham, Edward Elgar Publishing: 91-121.

Kotowska, I., (2012), 'Family change in Europe from a transition-to-adulthood perspective', in T. Knijn (ed.) Work, Family Policy and the Transition to Adulthood in Europe. Palgrave, Macmillan. Pp. 102-129.

Lazarus, R. S. and Folkman, S., (1984), Stress, Appraisal, and Coping. NY: Springer.

Le Bihan, B. and Martin, C., (2010), 'Reforming Long-term Care Policy in France: Public / Private Complementarities', Social Policy and Administration, 44(4):392-410.

Lewis, J., (2009a), Work-family balance, gender and policy, Edward Elgar, Cheltenham, UK.

Lewis, J., (2009b), 'Balancing 'time to work' and 'time to care': policy issues and the implications for mothers, fathers and children', Child and Family Law Quarterly, 21(4): 443-461.

Lewis, S. and den Dulk, L. van, (2008), 'Parents' experiences of flexible work arrangements in changing European workplaces: a multi-layer contextual approach', Sotziologitcheski problemi / Problèmes sociologiques, 49(2): 5-28.

Lewis, J., Knijn T., Martin C. and Ostner I., (2008), 'Patterns of development in work/family reconciliation policies for parents in France, Germany, the Netherlands and the UK in the 2000s', Social Politics. International Studies in Gender, State and Society, 15(3): 261-286.

Lewis, J. and Plomien, A., (2009), 'Flexicurity as a policy strategy: the implications for gender equality'. Economy and Society, 38 (3): 433-459.

Lippe, T. van der, (1993), Arbeidsverdeling tussen mannen en vrouwen. Amsterdam: Thesis Publishers.

Lippe, T. van der and P. Peters (eds), (2007),Competing Claims in Work and Family Life. Cheltenham: Edward Elgar.

Lippe, T. van der, A. Jager and Y. Kops, (2006), 'Combination pressure: the paid work-family balance of men and women in European countries' Acta Sociologica 49 (3) 303-319

Lyonette, C. and Clark, M.(2009) 'Unsocial hours: unsocial families? Working time and family wellbeing', An overview of the literature relating to atypical work and family wellbeing Warwick: Warwick Institute for Employment research/ Relationships Foundation

Martin C. (2010), "The Reframing of Family Policy in France: Actors, Ideas and Instruments", Journal of European Social Policy, 20 (5), p. 410-421. 
Mustomäki, Anttila, Oinas and Nätti, (2011), 'Job Quality trends in Europe - Implications for work-life balance', in S. Drobnic and A.M. Guillén (eds), Work-Life Balance in Europe. The Role of Job Quality. Hampshire: Palgrave Macmillan: 17-41.

OECD Employment Outlook, (2012)

Ostner, I., (2004), “What are children for?': Reciprocity and Solidarity between Parents and Children', in T. Knijn and A. Komter (eds), Solidarity Between the Sexes and the Generations. Transformations in Europe. Cheltenham: Edward Elgar: 167-184.

Plantenga, J., Remery, Ch. and Takacs, J., (2012), 'Public support to young families in the European Union', in T. Knijn (ed.), Work, Family Policies and Transitions to Adulthood in Europe, Basingstoke Hampshire: Palgrave Macmillan.

Roberts, K., (2007), 'Work-life balance - the sources of the contemporary problem and the probable outcomes: A review and interpretation of the evidence', Employee Relations, 29(4): $334-351$.

Saraceno, C. (ed.), (2008), Families, Ageing and Social policies. Intergenerational Solidarity in European Welfare States. Cheltenham: Edward Elgar Publisher.

Scheiwe, K. and Willekens, H. (eds), (2009), Child Care and Preschool Development in Europe. Institutional Perspectives. Basingstoke: Palgrave Macmillan.

Ungerson, C. and Yeandle, S. (eds.), (2007), Cash for Care in Developed Welfare States, London: Palgrave.

Weiten, W. and Lloyd, M.A., (2008), Psychology Applied to Modern Life (9th ed.), Wadsworth Cengage Learning. 